\title{
The Poem
}

\section{Beth Jude McGuinness}

\section{MAAT Year 32018}

I put you in the poem

I needed the poem

to hold you

Because

I couldn't

So this therapist said

every week

she sends angels out ahead

to watch over her clients

While

that might seem silly

to some

This poem has a heartbeat

a steady breath

This poem has a loyal body

like a dog

This poem has long arms

that reach around

everything

I trust the poem

to make room for you

I put you in the poem

I needed the poem

to hold you

Because

I couldn't 
This poem has a heartbeat

a steady breath

This poem has a loyal body

like my dog

I trust the poem 